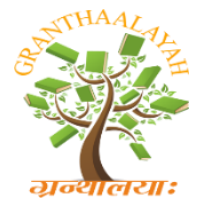

INTERNATIONAL JOURNAL OF RESEARCH GRANTHAALAYAH A knowledge Repository

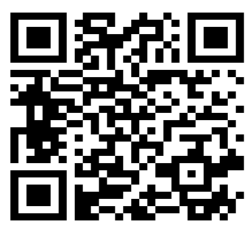

Science

\title{
STUDY OF THE COMPATIBILITY OF A DRILLING FLUID FORMULATED IN A MICROEMULSIONED SYSTEM WITH CEMENT SLURRY
}

\author{
Giovanna Laís R. Leal ${ }^{1}$, Fabíola D. S. Curbelo *1, Alfredo Ismael C. Garnica ${ }^{1}$, Raphael R. \\ Silva ${ }^{1}$, Tarsila M. Tertuliano ${ }^{1}$, Júlio César O. Freitas ${ }^{2}$, Evanice M. Paiva ${ }^{1}$ \\ ${ }^{1}$ Department of Chemical Engineering, Federal University of Paraiba, Brasil \\ ${ }^{2}$ Chemical Institute, Federal University of Rio Grande do Norte, Brasil
}

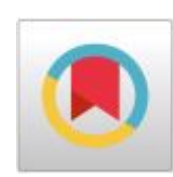

\begin{abstract}
In the cementing operation, it is necessary that the entire circumference of the annular is filled by the cement slurry and that it develops adhesion to the casing and formation. For this, an efficient removal of the drilling fluid is necessary, which requires that its chemical composition is compatible with that of the cement slurry. The objective of this work is to formulate a drilling fluid in a micro emulsified system and test its compatibility with the cement slurry to assess the effects that an unwanted contamination can have on the properties of the slurry. In the compatibility test, the rheological properties and the compressive strength of cement slurry contaminated with drilling fluid in different volumetric proportions were evaluated. The compressive strength of the cement slurry was determined, and the loads that the paste supports were checked. The compatibility test showed no visual changes in the properties of the slurry, although, after the addition of the drilling fluid, there was a decrease in the compressive strength.
\end{abstract}

Keywords: Microemulsion; Drilling Fluid; Cement Slurry; Compatibility.

Cite This Article: Giovanna Laís R. Leal, Fabíola D. S. Curbelo, Alfredo Ismael C. Garnica, Raphael R. Silva, Tarsila M. Tertuliano, Júlio César O. Freitas, and Evanice M. Paiva. (2020). "STUDY OF THE COMPATIBILITY OF A DRILLING FLUID FORMULATED IN A MICROEMULSIONED SYSTEM WITH CEMENT SLURRY." International Journal of Research - Granthaalayah, 8(3), 1-9. https://doi.org/10.29121/granthaalayah.v8.i3.2020.117.

\section{Introduction}

Well drilling has been conducted since ancient times for the purpose of finding water. The intensive search for oil began in the $19^{\text {th }}$ century with industrialization and, consequently, increased world demand for oil products. Initially, the wells were drilled by percussion methods at low depth using water or suspensions formed with local clays as drilling fluids. With technological development, wells have been opened by rotating equipment at extremely high depths and using increasingly complex fluids (BALTAR e LUZ, 2003). 
Drilling fluids are complex mixtures of solids, liquids, chemicals and, sometimes, even gases. Chemically, they may assume suspension, colloidal dispersion or emulsion aspects, depending on the physical state of the components (THOMAS, 2004).

According to CAENN et al. (2014), drilling fluids consist of a dispersing phase and a dispersed phase. The classification of a drilling fluid is based on its composition. The main criteria for classification is based on the main constituent of the dispersing or continuous phase and can be separated into water based fluids, oil based fluids and pneumatic (air, gas, foam). If the continuous phase is oil, the fluid is oil based, if the continuous phase is water then the fluid is water based. Gas-based fluids include those where gas is the continuous and discontinuous phase (SANTOS, 2012).

Microemulsion fluids appear as a viable alternative because of their high lubricity, stability, low cost and formation of a smooth and thin mudcake, characteristics that are aggregated by the microemulsion.

Cementing of oil wells is a post-drilling operation and occurs by pumping the cement slurry through the casing to fill the annular space formed between the casing and the well walls (LIMA, 2012; THOMAS, 2004). The process of cementing presents three main functions: supporting the coating, protecting the coating from corrosion and isolating one formation from another, preventing communication between coating and formation (GORDON et al. 2008).

Cement pastes and drilling fluid are generally incompatible, resulting in gelation at the cement/ mud interface, which reduces displacement efficiency. Another problem concerns the mudcake formed on the well walls during drilling, which may result in poor cement adherence to the well walls. In an attempt to circumvent such problems, fluids called spacers are pumped (OLIVEIRA, 2014; QUINTERO and MONTEIRO, 2012; CURBELO et al., 2018). The importance of cement slurry compatibility with drilling fluid is given because the spacer does not always completely remove fluid from the well walls, causing chemical reactions or undesirable physical modifications caused by contact of the cement slurry with likely fluid remnants.

The drilling fluid formulated in this work was water based which, according to MELO (2008), are the most used because they are cheaper, simpler to treat, have less pollution risks, affect less the penetration rate and more easily detect the presence of gas.

The oil-based fluid has long been widely used due to its high efficiency as a corrosion inhibitor. However, one of the major problems of this type of fluid is its disposal in the environment, because its compounds, being rich in diesel and mineral oils, tend to persist for many years in the environment (DUARTE, 2004).

Vegetable oils present a real alternative for drilling fluid application and as a substitute for diesel oil and paraffin. Being a renewable resource of agricultural or forest origin. The implementation of the energy use of plants has environmental, social and economic advantages and can be considered as an important factor for the sustainable development (SILVA NETO, 2002).

The objective of this work was to formulate an environmentally friendly microemulsion drilling fluid and to perform compatibility testing between this fluid and the cement slurry in order to 
evaluate the main effects that an unwanted contamination could have on the properties of a cement slurry.

\section{Materials and Methods}

The reagents used in the construction of the ternary phase diagram and subsequent formulation of the drilling fluid were: pine oil as an oil phase, glycerin as aqueous phase and nonionic surfactant Ultranex NP100. Moreover, as additives: xanthan gum, calcium bentonite, lime, HP-starch, baritine and water. For the compatibility test and compressive strength test, a cement slurry was used.

\subsection{Obtaining the Ternary Phase Diagram}

For the construction of the ternary phase diagram, Ultranex NP100 nonionic surfactant, commercial pine oil as an oil phase and a 1: 1 by mass aqueous glycerin solution as an aqueous phase were used.

The ternary phase diagram was obtained using the mass fraction titration methodology, in which the ratio of two components of the diagram was fixed for later titration with the third component until the appearance of a single phase, then determining the mass fractions of the components. This procedure was performed for several samples with different compositions to cover the entire length of the diagram. The obtained results were plotted in the ternary diagram

\subsection{Determination of The Specific Mass and Ph of the Drilling Fluid}

The drilling fluid density was determined on a mud balance Fann Model 140 according to API (2005). The measurement was obtained by displacing a sliding weight in order to even the balance with reference to a bubble level. The $\mathrm{pH}$ was determined using the $\mathrm{pH}$ meter (TECNOPON mPA 210). The reading of the device is done according to the reading of millivolts that the electrode generates when it is submerged in the collected fluid sample. Therefore, these millivolts are converted to a pH scale (SANTOS, 2012).

\subsection{Drilling Fluid Preparation}

After selecting a point from the microemulsion region of the diagram, a water-based drilling fluid was formulated. The fluid was prepared from $500 \mathrm{~g}$ of microemulsion and then the additives were added, under constant agitation, at a speed of $900 \mathrm{rpm}$, on Hamilton Beach shaker, respecting an interval of 8 minutes between each addition. Each additive plays a fundamental role in fluid formulation. Table 1 shows the quantity and function of each additive.

\begin{tabular}{|l|c|l|}
\hline Additive & Amount & Function \\
\hline Lime & $16.7 \mathrm{~g}$ & alkalizing \\
\hline Clay & $6.7 \mathrm{~g}$ & rheological modifier \\
\hline Hydroxypropyl starch & $1.7 \mathrm{~g}$ & filtrate reducer \\
\hline Xanthan Gum & $0.85 \mathrm{~g}$ & rheological modifier \\
\hline Barite & $85.0 \mathrm{~g}$ & densifying \\
\hline Water & $450 \mathrm{~g}$ & dispersion medium \\
\hline
\end{tabular}




\subsection{Filtrate Volume}

The filtrate volume was performed through static filtration in an API Press Filter pressurized by Fann. The fluid was stirred for 15 minutes and then transferred to the filter press container, in which a constant pressure of 100 psi was applied for 30 minutes with compressed air at a temperature of approximately $26^{\circ} \mathrm{C}$. With the aid of a sample, the filter volume was determined 30 minutes after the start of the pressure application.

\subsection{Compatibility Test}

Initially, the drilling fluid was stirred in the Hamilton Beach shaker for 15 minutes, in order to ensure sample homogeneity during the compatibility test. Subsequently, the drilling fluid (DF) and the cement slurry (CS) were conditioned in the atmospheric consistometer RCA-1200 (Chandler), under constant agitation, until reaching a temperature of $88^{\circ} \mathrm{C}$, according to the API Standard RP 10B $-2,2013$. Then, the cement slurry was mixed with the fluid, in volumetric proportions $95 \mathrm{DF} / 5$ CS, 75 DF/25 CS, 50 DF/50 CS, 25 DF/75 CS and 5 DF/95 CS (v/v) (Table 2). The slurry and fluid volumes were measured in a measuring cylinder and mixed in a beaker. After mixing, fluid deflection angle readings were performed using the Fann 35A viscometer at rotation speeds of $300,200,100,60,30,20,10,6$ and $3 \mathrm{rpm}$. The fluids are considered compatible when the readings of the deflection angle of the mixtures are close to the readings of the pure fluids, thus ensuring that there was no significant change in the viscosity of the pumped fluid, consequently, not compromising the operation.

Table 2: Composition of samples prepared for compatibility test.

\begin{tabular}{|c|c|}
\hline Sample & DF/CS (\%) \\
\hline M1 & $95 / 5$ \\
\hline M2 & $75 / 25$ \\
\hline M3 & $5 / 95$ \\
\hline M4 & $25 / 75$ \\
\hline M5 & $50 / 50$ \\
\hline
\end{tabular}

After mixtures were done, it was verified whether they showed, visually, signs of incompatibility, such as excessive increase in viscosity, sedimentation and phase separation.

\subsection{Compression Test}

The test was carried out with the objective of determining the mechanical resistance which the samples of the cement slurry contaminated with the drilling fluid will present in the oil wells. The volumetric proportion used was $90 \mathrm{CS} / 10 \mathrm{DF}$, according to the standard API RP10B2, 2013.

For the cement slurry formulation, Portland cement of special class was used, as it was developed to meet the cementation operations of oil wells in the onshore scenario in Brazil and follows the standard NBR 9831, 2006.

The compressive strength of cement slurry contaminated with drilling fluid was determined using Chandler Engineering's Model 4262 Ultrasonic Cement Analyzer (UCA). The conditions established for the test were $234^{\circ} \mathrm{F}$ and $20.7 \mathrm{MPa}$ for 24 hours. 


\section{Results and Discussion}

\subsection{Ternary Phase Diagram}

Fig. 1 shows the ternary phase diagram consisting of pine oil, aqueous glycerin solution, in a volumetric ratio of 1:1, and Ultranex NP100.

For the fluid formulation, a point in the microemulsion region (Winsor IV) was chosen, composed, in mass fraction, of $40 \%$ surfactant (S), 55\% aqueous phase (AP) and $5 \%$ oily phase (OP). This point was selected in order to decrease the cost of drilling fluid by reducing the amount of surfactant and increasing the proportion of the aqueous phase.

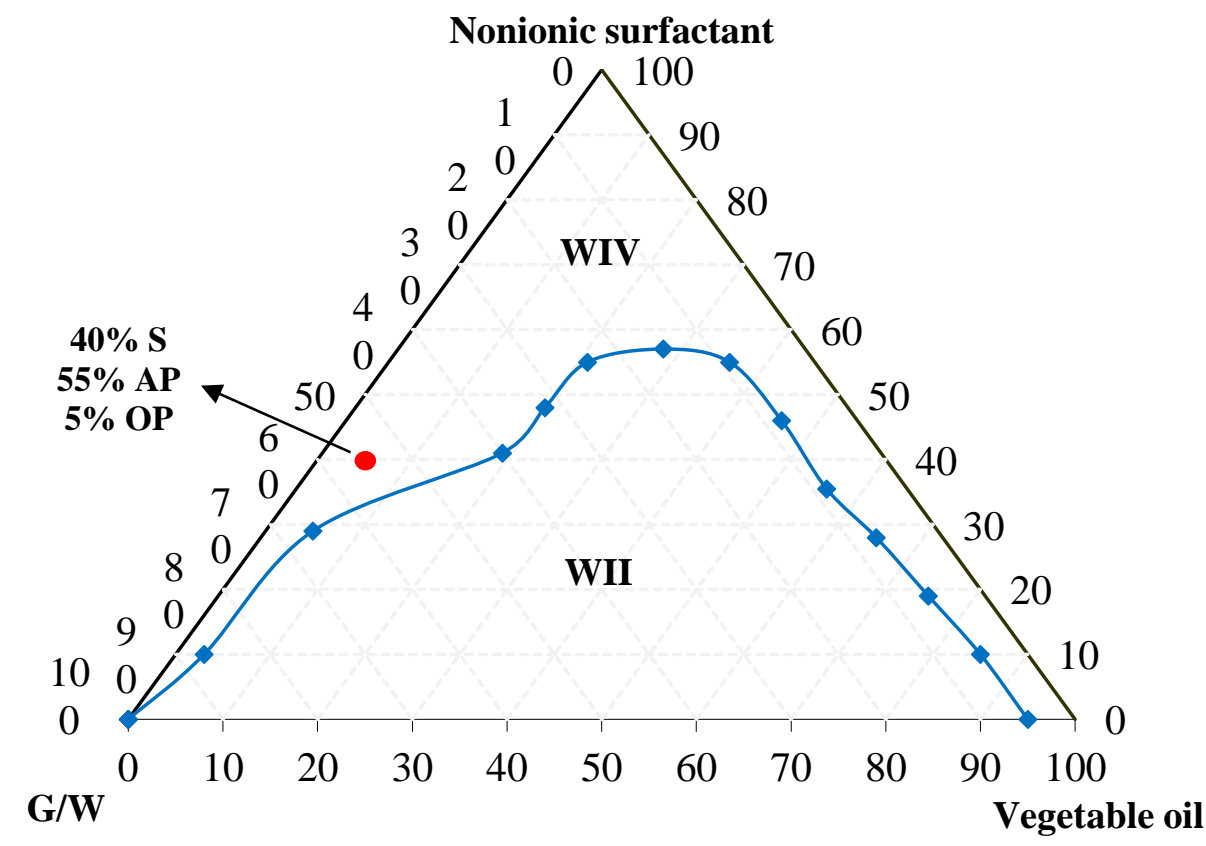

Figure 1: Diagram referring to the system composed of a solution of glycerin, Ultranex NP100 and pine oil.

\subsection{Specific Mass and $\mathbf{p H}$}

The specific mass of the formulated fluid was $1.01 \mathrm{~g} / \mathrm{cm}^{3}$, this result being acceptable according to the standard PETROBRAS N-2604 (1998), which determines that the specific mass of the fluids must be in the range of between 1 and $2 \mathrm{~g} / \mathrm{cm}^{3}$. According to SEED (2009), the control of the specific mass is important, since it influences the pressure loss due to friction in the turbulent regime and the flow through holes, besides serving as an indication of a possible contamination by formation fluids.

The $\mathrm{pH}$ obtained for the formulated fluid was 8.28, also meeting the requirements established by PETROBRAS N-2604 (1998), which corresponds to the range from 7 to 9. According to THOMAS (2004), the main objective is to reduce the rate corrosion of the equipment and avoid dispersion of clay formations. In this fluid, the $\mathrm{pH}$ control was done by adding lime. 


\subsection{Filtrate Volume}

The filtrate, if not properly controlled, can cause several problems, such as: excessive invasions in the geological formations; collapse of hydrable formations; mistakes in the evaluation of the formation being drilled; reduction of the diameter of the well and imprisonment of the drilling column, which strongly contributes to the differential sticking process (FARIAS et al, 2006).

Thus, the filtrate volume of $2.2 \mathrm{~mL}$ of the formulated fluid was satisfactory, corresponding to a low invasion of the filtrate, a thin mudcake and, consequently, less risk of occurrence of differential sticking, characteristics that guarantee its use in oilfield applications.

\subsection{Compatibility Test}

The rheological test was performed with mixtures M1, M2, M3, M4 and M5, the proportions of which are shown in Table 2. After this procedure it was possible to evaluate the compatibility between the drilling fluid and the cement slurry. Figure 2 represents the flow curve for the results of the rheological test.

As it is shown in Fig. 2, there is a variation in the rheological behavior of the cement slurry contaminated with the fluid. This can be explained by the contact of the cement slurry with the particles present in the fluid, such as clay, xanthan gum, among other compounds that alter the viscosity of the cement.

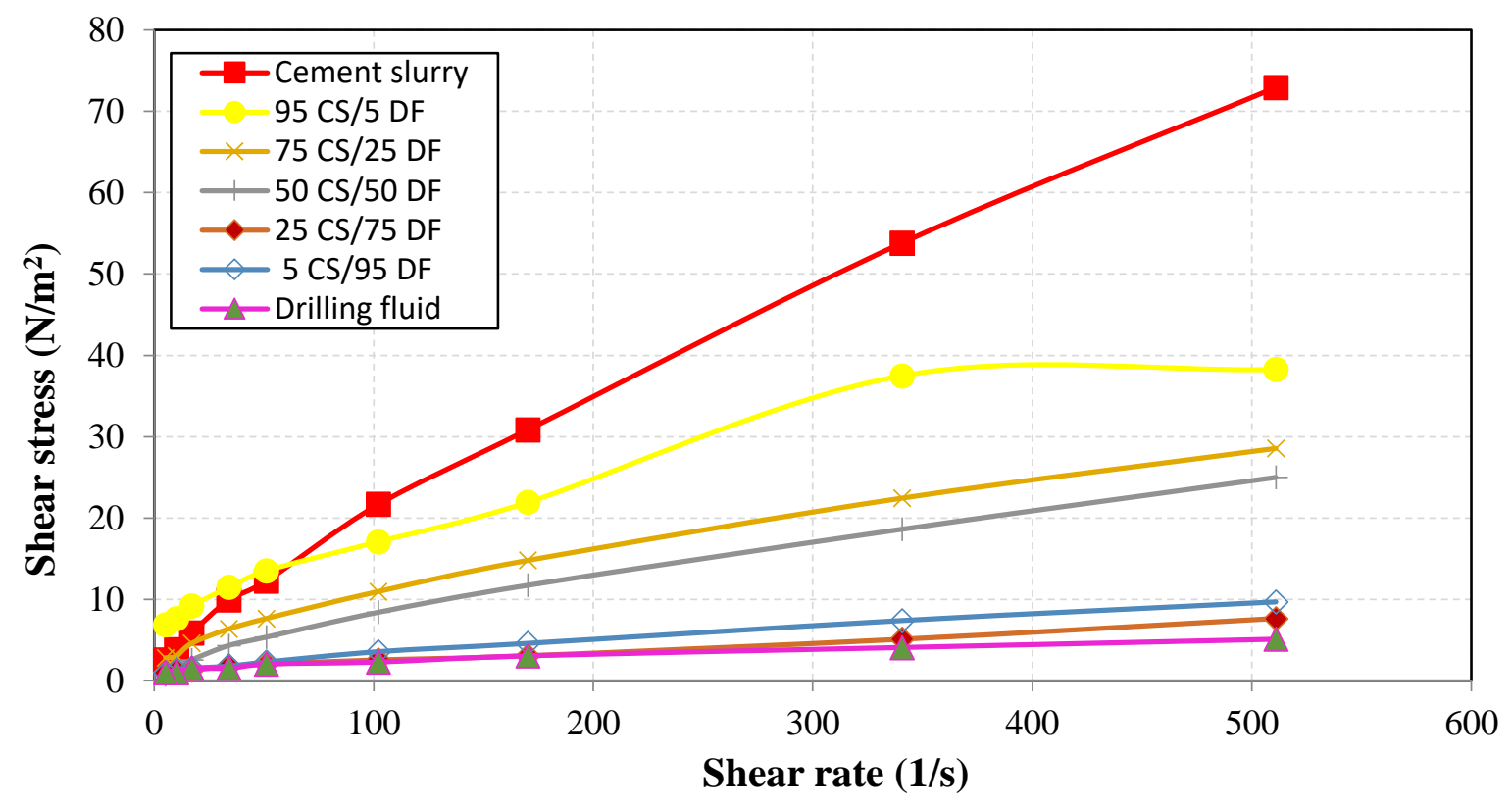

Figure 2: Flow curves.

Still in Fig. 2, analyzing only pure fluids (DF and CS), it is clear that they are incompatible due to the great difference in viscosity that exists. However, it appears that the flow curves corresponding to the mixtures are found between the curves of pure fluids, so it is concluded that these fluids are compatible when mixed in these proportions, without causing problems in cementing the well. 
Fig. 3 shows the samples used in the compatibility test. Visually, it can be seen that the mixtures did not show signs of incompatibility, such as excessive increase in viscosity, sedimentation or phase separation.

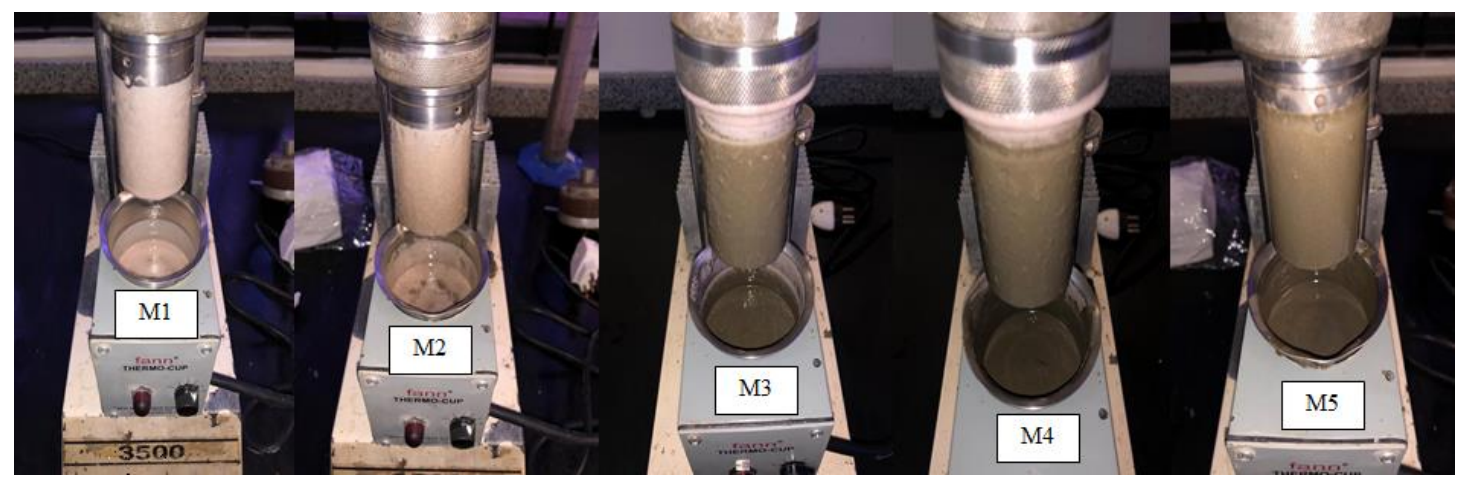

Figure 3: Mixtures between DF and CS.

\subsection{Resistance to Compression}

Fig. 4 shows the reduction in compressive strength when the cement slurry was contaminated by drilling fluid formulated in the proportion of $90 \mathrm{CS} / 10 \mathrm{DF}$, which may be associated with the formation of microcavities, a factor that has an inverse relationship with the resistance. The particles coming from the fluid form an impermeable layer over the cement slurry, which consequently dehydrates faster, making it more fragile.

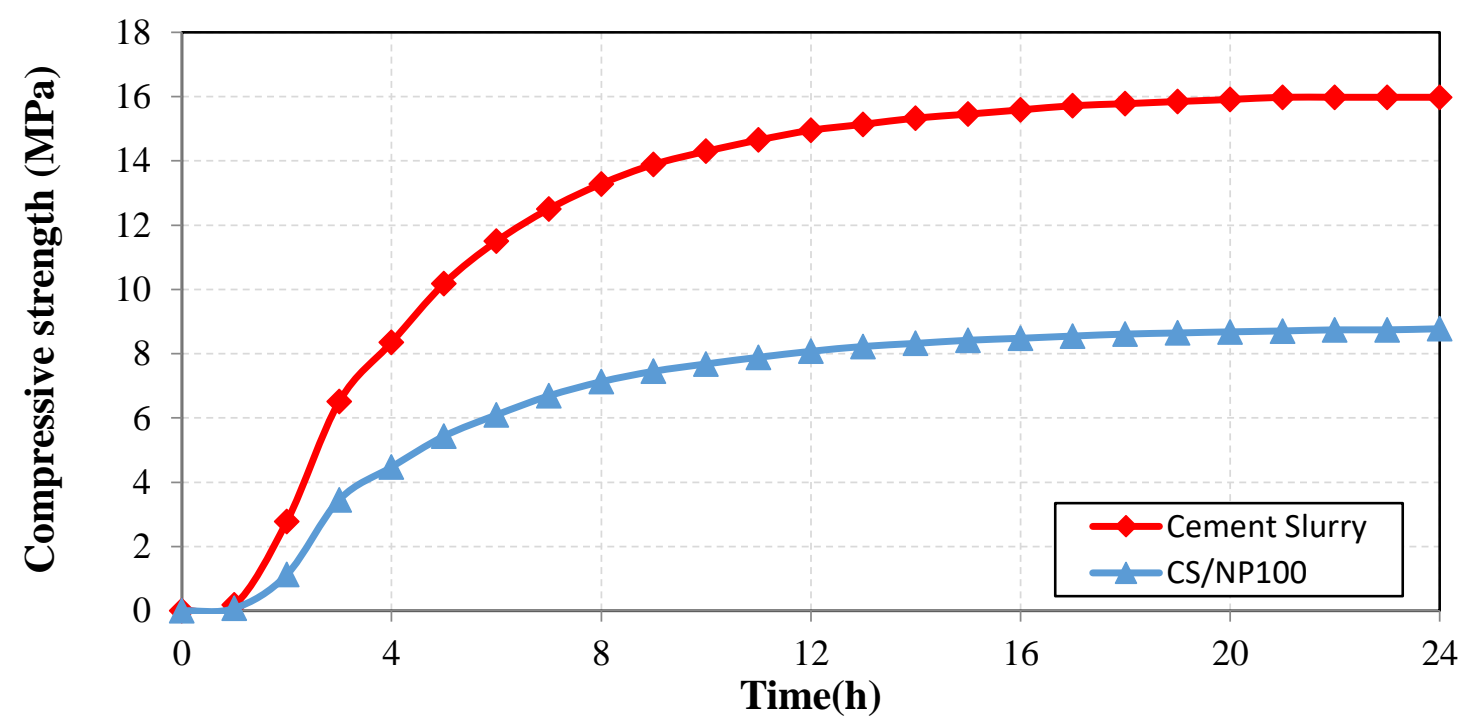

Figure 4: Compressive strength as a function of time.

\section{Conclusions and Recommendations}

The fluid obtained showed satisfactory results, meeting the recommended specifications, in addition to presenting itself as a sustainable and environmentally acceptable alternative, as it makes use of glycerin, vegetable oil and biodegradable surfactant. 
Compatibility between fluids was verified in all proportions. As all the mixtures, besides being able to keep the cuttings in suspension, obtained viscosities lower than that of the cement slurry, it appears that the contamination of the slurry will not compromise its displacement in the well during cementation.

Despite the compatibility between fluids, after 24 hours of continuous monitoring of the compressive strength, it was possible to observe that the resistance to the contaminated mass decreased, it was observed in the pure cement mass. The result was 1276 psi or $8.8 \mathrm{MPa}$, which is below the minimum resistance required for well drilling projects, which is $1500 \mathrm{psi}$ or $10.34 \mathrm{MPa}$.

\section{References}

[1] API Petroleum and natural gas industries - Field testing of drilling fluids. Part 1: water-based fluids, Washington, 2005.

[2] API (American Petroleum Institute). API Recommended Practice 10B-2: Recommended practice for testing well cements. $2^{\mathrm{a}}$ edição, 2013.

[3] Baltar, C. A. M., Luz, A. B. Insumos Minerais para Perfuração de Poços de Petróleo. - Rio de Janeiro: CETEM/UFPE, 2003.

[4] Associação Brasileira De Normas Técnicas. Cimento Portland Destinado à Cimentação de Poços Petrolíferos: Requisitos e Métodos de Ensaio. NBR 9831. Rio de Janeiro, 2006.

[5] Caenn, R., Darley, H. C. H, Gray, G. Fluidos de Perfuração e Completação: Composição e Propriedades, $1^{\text {a }}$ ed., Rio de Janeiro: Elsevier, 2014.

[6] Curbelo, F. D. S., Garnica, A. I. C., Araújo, E. A., Paiva, E. M., Cabral, A. G., Araújo, E. A., Freitas, J.C.O. Vegetable Oil-Based Preflush Fluid in Well Cementing. Journal Of Petroleum Science And Engineering, Vol. 170, 2018, 392-399. doi.org/10.1016/j.petrol.2018.06.061.

[7] Duarte, R. G. Avaliação da Interação Folhelho-Fluido de Perfuração para Estudo de Estabilidade De Poço. Master's thesis in Civil Engineering. Pontifícia Universidade Católica do Rio de Janeiro, Rio de Janeiro, 2004, 121 p. doi.org/10.17771/PUCRio.acad.5163

[8] Farias, K. V., Amorim, L. V., Ferreira, H. C., Pereira, E. Estudo da Reologia e Espessura do Reboco de Fluidos de Perfuração: Influência de Dispersantes e Umectante Aniônicos. Cerâmica, Vol. 52, No. 324, 2006, 307-314. doi.org/10.1590/S0366-69132006000400015

[9] Gordon, C.; Lewis, S.; Tonmykayakul, P. Rheological Properties of Cement Spacer: Mixture Effects. AADE-08-DF-HO-09, Houston, Texas, April 8-9, 2008.

[10] Lima, F. M. Estudo de Sistemas de Colchões Lavadores para Aplicação em Poços Perfurados com Fluidos de Perfuração Não Aquosos. Master's thesis in Chemical Engineering. Universidade Federal do Rio Grande do Norte, 2012, 133 p.

[11] Melo, K. C. Avaliação e Modelagem Reológica de Fluidos de Perfuração Base Água. Master's thesis in Chemical Engineering. Universidade Federal do Rio Grande do Norte, Natal, 2008, 100 p.

[12] Oliveira, L. A. Desenvolvimento de uma Ferramenta Computacional para Simulação de Operações de Cimentação Primária. Curso de Engenharia Química, Universidade Federal do Rio Grande do Norte, Natal, 2014.

[13] PETROBRAS, Viscosificante para Fluidos Base Água na Exploração e Produção de Petróleo, N2604, 1998.

[14] Quintero, L., Monteiro, O. R. Heat Removal in Drilling and Production Operations. United States patent US 9,016,374 B2. 2012 Apr. 4.

[15] Santos, M. B. Perfuração de Poços de Petróleo: Fluidos de Perfuração. Bolsista de Valor: Revista de Divulgação do Projeto Universidade Petrobras e IF Fluminense, Vol. 2, No. 01, 2012, 121-127.

[16] SEED. Manual de Treinamento em Controle de Poço, 2009. 150 p. 
[17] Silva Neto, M. A. Contribuição Técnica de um Sistema de Emulsão Inversa À Base de Óleo Vegetais para Fluidos de Perfuração. Master's thesis in Chemical Engineering, Universidade Federal do Rio Grande do Norte, Natal, 2002.

[18] Thomas, J. E. Fundamentos de Engenharia de Petróleo. $2^{a}$ ed. Interciência, 2004

*Corresponding author.

E-mail address: fabioladias@yahoo.com 